\title{
Poverty Occurrency Probability On Oil Palm Farmer Households
}

\author{
Nyayu Neti Arianti ${ }^{*}$, Muhammad Harismanto, and Agus Purwoko \\ Department of Agricultural Socio-Economics, Faculty of Agriculture, University of Bengkulu, \\ Bengkulu, Indonesia. \\ *Email address: nnarianti@unib.ac.id
}

\begin{abstract}
The research was aimed at analysing poverty level of non-plasma oil palm famer households and determining factors that influence on their poverty occurency probability. This research was conducted by surveying ninety non-plasma oil palm farmer households in Mukomuko District. The poverty level was quantified method by comparing household income with the World Bank poverty line, i.e. US \$ 2 /capita/day. Households were categoried into poor if their income is les than US $\$ 2 /$ capita/day or Rp $26,908.00$ /capita/day (with exchange rate of Rp 13,454.00 per US \$), vice versa. To determine factors affecting the probability of poverty occurency, the binary logistic model was applied. The results showed that the average non-plasma farmer household income was $\mathrm{Rp} \mathrm{39,484.00/capita/day.} \mathrm{With} \mathrm{the} \mathrm{level} \mathrm{of}$ exchange rate applied in this research, it was found that forty percent households were under poverty line. Land variable negative and significantly affects the probability of poverty occurency while familiy size were positive significant. Other factors including education, age, and the exixtence of other jobs had insignificant effect.
\end{abstract}

Keywords: probability, poverty, oil palm, household Citation to this paper should be made as follows :

Arianti, N. N., M. Harismanto, and A. Purwoko. 2018. Poverty Occurrency Probability on Oil Palm Farmer Households. Agritropica: Journal of Agricultural Science. 1 (1): 56-61. DOI: https://doi.org/10.31186/J.Agritropica.1.1.56-61

\section{INTRODUCTION}

One of the national development goals is to improve the economic performance for creating jobs, erradicating poverty and improving the Indonesian welfare. However, poverty still becomes a serious problem that have to be faced by Indonesian governments. Poverty is a complex and multidimensional problem. This required great and comprehensive efforts to alleviate poverty by covering various aspects of community life, and implemented in an integrated manner (Nasir et al, 2008).

Based on the latest data from Indonesia's Statistics Agency (BPS, 2017), Indonesia's absolute poverty rose to 27.77 million people in March 2017 compared to 27.76 million in September 2016. However, the country's relative poverty figure fell from 10.70 percent in September 2016 to 10.64 percent of the population in March 2017. The data also informs that most of them are living in rural area, 13.47 percent compared to 7.26 percent who are living in city area. Discussion on poverty in rural areas cannot be alienated from the agricultural sector in which most rural population are dependent on it.

The agricultural sector is the leading sector is almost in all districts in Bengkulu province, including in District of Mukomuko. This sector has large contribution to Gross Regional Domestic Product (GRDP), i.e., 46.10 percent of total GRDP. Data published by BPS (2015) informed that food crop, livestock, hunting and agricultural services are the largest contributors, i.e., 68.51 percent, in creating value added. In addition, among agricultural sector, 
estate or plantation subsector plays an important role especially in providing jobs.

Plantation in Mukomuko district is dominated by oil palm estate covering 78.19 percent of total estate area of $117,444.04$ ha in 2014 (BPS 2015). This estate is categorized into smallholders and private etates. Smallholder estates are divided into non-plasma and plasma estate. Non-plasma estate is managed and developed by smallholders themselves while plasma is developed and managed under guidance of private estates. Generally, nonplasma plantations are characterized by low production, poorly maintained garden conditions, and low incomes. The low productivity of non-plasma oil palm plantations is also caused by the limited capital owned by farmers. Furthermore, as exported commodity, fresh fruit bunch (FFB) price recieved by famers is also influenced by Crude Palm Oil (CPO) price at the world market. As a result, oil palm farmers are vulnerable when they face volatility of FFB prices. Study by Sukiyono, et al. (2017) showed that oil palm farmers tend to be vulnerable when their FFB price is more that 53 lower than production cost. A similar question arised is that how their probabilities to be poor and what factors influence their probabilities to be poor. This paper is aimed at answering these questions.

\section{RESEARCH METHODS}

This study was conducted on 27 April to 4 May 2016 in Mukomuko District. The research is focussed on non plasma farmers and intervews 90 oil palm farmers. Household poverty rate is measured by using poverty line indicators proposed by World Bank (2007). World Bank (2007) defines poverty as a less prosperous society and expressed in a single

$$
g(x)=\ln \frac{\pi(x)}{1-\pi(x)}=\beta_{0}+\beta_{1} A R E A_{t}+\beta_{2} S I Z E_{t}+\beta_{3} E D U_{t}+\beta_{4} A G E_{t}+\beta_{5} J O B S_{t}+\mu_{t}
$$

The model is estimated with Maximum Likelihood Estimation (MLE) then followed by goodness fit test and t-test for determining a currency or common currency, namely US Dollar (US \$). US \$ is chosen as a reference because it is acceptable in almost all countries. Furthermore, World Bank (2007) establishes an international poverty line of the US $\$$ $2 /$ capita/day. This is the median of the poverty line of all developing countries. The household is categorized as a poor if its daily income is below US \$2/capita/day or US \$ $60 /$ capita/month (depending on the exchange rate), vice versa.

To determine factors that influence the farmers' probability to be a poor, Binary Choice Model or Linear probability model in Logit form is applied. The binary choice of the i-th individual is expressed in the form of an irandom variable having a value of 1 if one of the alternative options is taken and a value of 0 when the alternative of the other option is taken (Pindyck and Rubinfeld, 1991). The categories formed are: $\mathrm{Yi}=1$ (poor) and $\mathrm{Yi}=0$ (not poor).

The general form of the logistic regression opportunity model with the explanatory variable $\mathrm{p}$, is formulated as follows :

$$
\begin{aligned}
& \pi(x)=\frac{\exp (\beta 0+\beta 1 X 1+\cdots+\beta p X p)}{1+\exp (\beta 0+\beta 1 X 1+\cdots+\beta p X p)} \\
& \Pi(x) \text { is the probability of a success event }
\end{aligned}
$$
with probability value $0 \leq \Pi(x) \leq 1$ and $\beta$ is the parameter value with $j=1,2,3 \ldots, p . \Pi(x)$ is a non-linear function, so it needs to be transformed into logit form to obtain linear function in order to see the relationship between independent variables, i.e., land area (AREA), the family size (SIZE), head of household formal education (EDU), head household age (AGE), and the existence of side jobs (JOBS) and with dependent variable of the probability of poverty occurency. After the transformation of the logit $\Pi(x)$, then a logit equation can be written as follws:

significant factor influencing poverty probability occurency. 


\section{RESULTS AND DISCUSSION}

\section{Household Poverty Rate}

Poverty line is determined by examining merely from oil palm household income. Income is one aspect of poverty and often used as a measure of relative poverty. As dicussed in research method, this paper uses a poverty line indicator of World Bank (2007), that is, US \$2/capita/ day or US \$ $60 /$ capita/month. With exchange rate of $\mathrm{Rp}$ $13.454,00$ per US $\$$, the poverty line used is $\mathrm{Rp}$ 26.908,00/capita/day.

The results show that household income of non-plasma oil palm farmers ranged from $\mathrm{Rp}$ 800,000 to $\operatorname{Rp} 28,200,000.00 /$ month with average of $\operatorname{Rp} 4,827,661.00 /$ month. Compared to World Bank poverty line, it is found that fourty percent of oil palm farmers fall into poor category. This occurence is due to the narrowness of land, on average of $1.84 \mathrm{Ha}$. Most of farmers, 97.78 percent, have land less than 5.5 Ha. Amar (2002) states that the poverty is relatively visible from the ownership of assets controlled by farmers, especially land. The uniform distribution of land tenure will greatly affect the distribution of people's income, so land becomes the main production factor for the community in creating family income. Furthermore, the increasing of assets, especially land managed by farmers will increase their income which in turn will reduce their probability to be poor. Figure 1 shows a distribution of oil palm farmers based on World Bank poverty line.

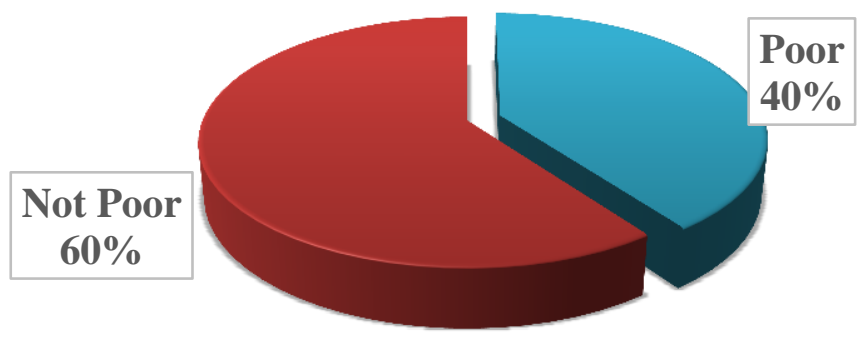

\section{Figure 1 Distribution of oil palm farmer households based World Bank Poverty line}

As shown in Figure 1, the percentage of oil palm farmer households under poverty line is 40 percent. This finding is relatively high. This finding is reasonable since survey was conducted during FFB price experincing a lower and volatile. In this period, many famers have also experinced a vunerable as found by Sukiyono, et al (2017). Furthermore, according to Pradhan et al (2000) in Tambunan (2003), agriculture is the sector with the highest poverty rate and also has the greatest contribution to the increase of poverty compared to other sectors. Increasing productivity and wage rates in the agricultural sector is a crucial effort to reduce rural poverty. Papanek and
Handoko (1999) in Tambunan (2003) stated that there is a strong correlation between poverty eradication and real wage increase in the agricultural sector.

\section{Probability of Poverty Occurence}

Factors that allegedly affected the probability of poverty occurence on nonplasma oil palm farmer households in Mukomuko Regency were land (AREA), family number (SIZE), formal education (EDU), age (AGE) and the existence of other jobs (JOBS). All variables simultaneously affected the poverty occurrence probability on non-plasma oil palm farmer households. This conclusion is drawn from LR statistic test that is lower than 
0.05. This finding implies that logistic model applied in this research can be used to explain variance of poverty occurence. The model estimation has also found that R-squared value is 0.20 indicating than independent variables are able to explain the probability of poverty occurrence by 20 percent.

Table 1. Model Estimation Result

\begin{tabular}{lccc}
\hline \multicolumn{1}{c}{ Variables } & Coefficient & Standard Error & Probability \\
\hline Land (AREA) & -7.77 & 3.14 & $0.01^{*}$ \\
Family Number (SIZE) & 0.66 & 0.20 & $0.00^{*}$ \\
Formal Education (EDU) & 0.14 & 0.10 & 0.17 \\
Age (AGE) & 0.05 & 0.03 & 0.16 \\
Other Jobs Existence (JOBS) & -0.24 & 0.68 & 0.72 \\
Constant & -5.62 & 2.26 & 0.01 \\
\hline R-squared $\quad=0.20$ & & & \\
a $=0.05$ & & & \\
Prob (LR statistic) $=0.000226$ & & & \\
\hline
\end{tabular}

Note: *) significant at 95 percent confidence level

The influence of each variable on the probability of poverty occurrence is explained as follows. The land variable had a negative significant effect on the probability of poverty occurrence on non-plasma oil palm farmer household in Mukomuko District. The value of Prob item (0.001) was lower than a (0.05) value at 95 percent confidence level. This infoms that AREA affects the probability of poverty occurence meaning that the wider Area ownwed by famers, the lower their probability to be poor, vice versa. The survey find that most of farmers has a norrow land area, as dicussed above, this condition will affect the probability of them to be poor. Farm area is the main source of farmers to generate their income. Low land area implies low income, thus, farmers with wider land area will have less probability to be poor. Antara (2006) also stated that land size contribute to decrease poverty level of farmers.

The model estimation also concludes that family number (SIZE) affected the probability of poverty occurrence positive and significantly. The probability of poverty will increase when the number of family increase, vice versa. The family number of non-plasma oil palm farmer households was ranged from two to eight peoples with an average of five peoples. According to BKKBN (2013) ideal family is a family of "caturwarga" consisting of father, mother, and maximum two children. The average of family number higher than the ideal number indicates that farmers should strive to provide for the whole family. With a fixed amount of income, the per capita income will decrease if the family number increase. This study is in accordance with research conducted by Nasir et al (2008) that the family number positively affect household poverty. The results of Sari (2012) study also showed that the number of dependents affecting the households poverty.

Three other factors including formal education (EDU), age of households head (AGE), and the existence of other jobs (JOBS) are not significant for determining the probability of poverty occurence. Those factors are insignificant at every significance level and do not have an expected sign with exception of JOBS. JOBS has a negative sign indicating that the existence of other jobs will evade farmers from being poor. This finding is reasonable since declining FFB price will affect total income earned by farmers and the existence of other income sources, farmers will be able to cope and fulfill their need. The survey finds that the majority of households, 88 percent, 
have other sources of income from both the agricultural sectors and non-agricultural sectors, i.e. as other commodity farmers, farm laborers, and traders. The average of household

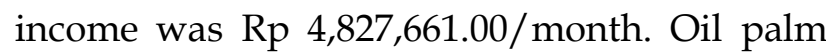
contributed 67.55 percent to total household income. Although the contribution of income from other jobs is relatively high but in absolute terms does not make households lifted from the poverty condition. Furthermore, The insignificant of EDU and AGE can be explained briefly as follows. Level of education as well as AGE are not directly related to poor condition. It tends to correlate with the ability of farmers to manage their estate and households. Event though farmers are able to manage their estate properly if the price of FFB is declining, then farmers will become a poor.

\section{CONCLUSIONS AND POLICY IMPLICATIONS}

The research conclude that forty percent of oil palm farmer households in Mukomuko District are categorized as poor. For this reason, government along with field extention officiers should provide more intensive counseling as an effort to increase the productivity of their oil palm plantations. Farmers' institutional strengthening also needs to be done to increase the bargaining power of farmers against sellers who are often dishonest.

The land and the family number had a negative and positive significant effects on the probability of poverty accurrence, while age, education and the other jobs existence had an insignificant effect. Developing other job opportunities in rural areas should be done due to increasing farmer household incomes.

\section{REFERENCES}

Amar. 2002. Kemiskinan Relatif terhadap Aset Rumahtangga. Accessed from http://semokernapai.wordpress.com. on January $26^{\text {th }} 2017$ at 05.30 a.m.
Antara, Made. 2006. Faktor-faktor yang Mempengaruhi Kemiskinan Petani di Sekitar Kawasan Taman Nasional Lore Lindu (Kasus di Desa Katu Kecamatan Lore Tengah Kabupaten Poso). Accessed from $\quad$ http://media.neliti.com/ media/publications/117109-ID-faktoryang-memengaruhi-kemiskinan-petan. pdf. on April 26 th 2018 at 10.48 a.m.

BKKBN. 2013. Program Keluarga Berencana. Accessed from http://bkkbn.com. on January $2^{\text {th }} 2017$ at 10.30 a.m.

BPS Kabupaten Mukomuko. 2015. Kabupaten Mukomuko dalam Angka 2015. BPS Kabupaten Mukomuko. Mukomuko.

Nasir, M. Saichudin and Maulizar. 2008. Analisis Faktor-faktor yang Mempengaruhi Kemiskinan Rumah tangga di Kabupaten Purworejo. Jurnal Eksekutif: 5(4) Agustus 2008. LIPI. Jakarta.

Pindyck, Robert S. and Daniel L. Rubinfeld. 1991. Econometric Models and Economic Forecasts. McGraw Hill, Inc. New York.

Sari, Ayula Candra Dewi Mulia. 2012. Pengaruh Kepemilikan Aset, Pendidikan, Pekerjaan dan Jumlah Tanggungan Keluarga terhadap Kemiskinan Rumahtangga di Kecamatan Bonang Kabupaten Demak. Accessed from http://core.ac.uk. on April 26 2018 at 00.24 p.m.

Sukiyono, Ketut, Indra Cahyadinata, Agus Purwoko, Septri Widiono, Eko Sumartono, Nyayu Neti Asriani and Gita Mulyasari. 2017. Assessing Smallholder Household Vulnerability to Price Volatility of Palm Fresh Fruit Bunch in Bengkulu Province. International Journal of Applied Business and Economic Research. 15 (3): 1 - 15. 
Tambunan, Tulus T.H. 2003. Perekonomian Indonesia, Beberapa Masalah Penting. Ghalia Indonesia. Jakarta.
World Bank. 2007. Repositioning Nutrition as Central to Development. A Strategy for Large-Scale Action. World Bank. Washington DC. 